\title{
Heavy Metal Concentrations around a Hospital Incinerator and a Municipal Dumpsite in Ibadan City, South-West Nigeria
}

\section{${ }^{* 1}$ TIMOTHY AUTA; ${ }^{2}$ OLAJUMOKE A. MORENIKEJI}

\author{
${ }^{1}$ Department of Biological Sciences, Federal University, Dutsin-Ma, Nigeria
}

${ }^{2}$ Department of Zoology, University of Ibadan, Ibadan, Nigeria

Key words: Hospital incinerator, municipal dumpsite, heavy metals, Bottom ash.

\begin{abstract}
Studies to determine the concentrations of heavy metals in the surrounding soils and bottom ash of a hospital incinerator and a municipal dumpsite were carried out in Ibadan City, South-West Nigeria from November 2010 to January 2011. Samples were analyzed for $\mathrm{Pb}, \mathrm{Fe}, \mathrm{Cu}, \mathrm{Zn}, \mathrm{Cr}$ and $\mathrm{Ni}$ using Flame Atomic Absorption Spectrophotometry. Data obtained were analyzed using ANOVA, Students T-test and Pearson correlation. Mean concentrations of heavy metals in the sampled soils at the incinerator were $185.22 \pm 72.88$, $16.22 \pm 13.13,69.11 \pm 54.26,2.33 \pm 2.53,22.48 \pm 21.00$ and $0.58 \pm 0.30$ for $\mathrm{Fe}, \mathrm{Cu}, \mathrm{Zn}, \mathrm{Cr}, \mathrm{Pb}$ and $\mathrm{Ni}$ respectively, mean concentrations in the incinerator bottom ash were $5357.52 \pm 4671.89 \mathrm{mg} / \mathrm{Kg}, 938.2 \pm 428.42 \mathrm{mg} / \mathrm{kg}$, $10670 \pm 3852.44 \mathrm{mg} / \mathrm{kg}, 72.96 \pm 15.14 \mathrm{mg} / \mathrm{kg}, 427.2 \pm 197.69 \mathrm{mg} / \mathrm{kg}$ and $34.78 \pm 11.69 \mathrm{mg} / \mathrm{kg}$ for $\mathrm{Fe}, \mathrm{Cu}, \mathrm{Zn}, \mathrm{Cr}, \mathrm{Pb}$ and $\mathrm{Ni}$ respectively and mean concentrations in sampled soils of municipal dumpsite were $290.67 \pm 78.66 \mathrm{mg} / \mathrm{Kg}$, $7.86 \pm 1.68 \mathrm{mg} / \mathrm{kg}, 132.87 \pm 39.40 \mathrm{mg} / \mathrm{kg}, 2.58 \pm 1.48 \mathrm{mg} / \mathrm{kg}, 14.52 \pm 6.76 \mathrm{mg} / \mathrm{kg}$ and $0.79 \pm 0.26 \mathrm{mg} / \mathrm{kg}$ for Fe, Cu, Zn, $\mathrm{Cr}, \mathrm{Pb}$ and $\mathrm{Ni}$ respectively. ANOVA showed that $\mathrm{Fe}(\mathrm{F}=11.254), \mathrm{Cu}(\mathrm{F}=5.678), \mathrm{Zn}(\mathrm{F}=20.399)$ and $\mathrm{Pb}(\mathrm{F}=$ 3.679) had significant variations with sampling site, with bottom ash having the highest concentrations. The concentrations of heavy metals from both locations were higher than in the control site, indicating pollution. The heavy metal contents of the soils analyzed were all below the USEPA standard limits. However, the bottom ash contained high levels of $\mathrm{Zn}$ and $\mathrm{Pb}$, that exceeded the standard limits. There is a need to appropriately dispose off the bottom ash from incinerators.. @ JASEM
\end{abstract}

\section{http://dx.doi.org/10.4314/jasem.v17i3.11}

Human activities create wastes and it is the way these wastes are handled, stored, collected and disposed that constitutes risks to the environment and public health. In the urban areas, especially, in the rapidly urbanizing cities of the developing world, problems and issues of solid waste management are of immediate importance. This has been acknowledged by most governments. However, rapid population growth overwhelms the capacity of most municipal authorities to provide even the basic services. When wastes are collected, they are disposed-off in uncontrolled dumpsites and/or burnt, polluting water resources, air and soil (Onibokun, 1999).

Heavy metal soil contamination is particularly problematic because they are not degraded in soil. Heavy metals in soil cannot be permanently eliminated. At best they can be locally reduced by redistribution in the eco-system or removed from circulation by immobilization (Baker, et al., 1996). Heavy metals and their compounds have different physical and chemical characteristics and pose diverse toxicological characteristics. Human beings are poisoned through inhalation, ingestion and skin absorption. Acute exposures to high levels cause nausea, anorexia, vomiting, gastrointestinal abnormalities and dermatitis. Chronic exposures to heavy metals cause cumulative toxic effects, which affect various systems in the body depending on the heavy metal involved (Mahoney and Moy, 2005).

This research aimed at determining the heavy metals present in soils around a municipal dumpsite and the
University College Hospital incinerator and also in the bottom ash samples in the incinerator.

\section{MATERIALS AND METHODS}

Soil samples were collected around the University College Hospital (UCH) incinerator, Bashorun market dumpsite and from an open field in the University of Ibadan (Control) in Ibadan city, southwest Nigeria. Ibadan is reputed to be the largest indigenous city in Africa, south of the Sahara. Ibadan city comprises of 11 local government areas (5 urban and 6 sub-urban) and has a population of 2,550,593 according to 2006 census results covering an area of $128 \mathrm{~km}^{2}$ (National Population Commission, 2007).

The medical incinerator is the incinerator being currently used in Nigeria's oldest Teaching Hospital University of Ibadan College Hospital (UCH). This incinerator handles close to $300 \mathrm{~kg}$ of biomedical wastes daily (Coker et al, 2000). Plastics mainly Polyvinylchloride (PVC) products and absorbents which are major sources of air pollution constitute about $70 \%$ of the wastes being generated in this hospital. The incinerator is a locally - made earth brick furnace type with a kaolin - brick refractory (Coker, et al., 2000).

Surface soil samples were obtained at three different points; 10 metres apart starting from the base of the $\mathrm{UCH}$ incinerator and Basorun market dumpsite and at one point from the control site, for three consecutive months, November 2010 to January 2011. At each sampling point, four samples were collected at 
different directions and mixed to obtain a composite sample. The ash samples were obtained from the bottom of the incineration facility at different directions to make a composite sample. The samples were stored in labelled polythene bags and taken to the laboratory for treatment and preservation.

The soil and ash samples obtained were air-dried at ambient temperature in the laboratory for 5 days. The samples were then crushed using a porcelain mortar and pestle, then sieved through a $2 \mathrm{~mm}$ screen, then through a $0.2 \mathrm{~mm}$ screen to obtain a homogenous particle size. These were stored in separate polythene bags, appropriately labelled and stored for digestion and analysis

The samples were dissolved with $5-\mathrm{mL}$ of $6 \mathrm{M} \mathrm{HNO}_{3}$. The solution was boiled for 20 minutes on a hot plate to reduce the volume of the acid to about $2-\mathrm{mL}$. The digest was diluted with $10-\mathrm{mL}$ distilled water, and then filtered through Whatman No. 42 filter paper into a $50-\mathrm{mL}$ volumetric flask. The residue was washed several times until volume was made up to $50-\mathrm{mL}$. The resulting solution was stored in a precleaned polyethylene bottle until time for analysis All the soil and ash samples were analyzed for $\mathrm{Pb}, \mathrm{Fe}$, $\mathrm{Cu}, \mathrm{Zn}, \mathrm{Cr}$ and $\mathrm{Ni}$ using Flame Atomic Absorption Spectrophotometer, Buck Scientific Model 200-A, using appropriate lamps and resonance wavelength of the metals, at National Institute of Science and Laboratory Technology (NISLT), Ibadan.

Data obtained were subjected to analysis of variance (ANOVA) and Students' T-test analysis. A probability $\leq 0.05$ was considered as significant.

\section{RESULTS AND DISCUSSION}

Results show that $\mathrm{Fe}$ had the highest mean concentration of $185.22 \mathrm{mg} / \mathrm{kg}$ and $\mathrm{Ni}$ had the lowest, $0.58 \mathrm{mg} / \mathrm{kg}$ among the heavy metals found in soils around the $\mathrm{UCH}$ incinerator. The descending order of metal content was $\mathrm{Fe}>\mathrm{Zn}>\mathrm{Pb}>\mathrm{Cu}>\mathrm{Cr}>\mathrm{Ni}$. All the metal concentrations in soil were below the USEPA regulation limits (Table 1). The concentrations of heavy metals in these soils are very low compared to that of polluted soils in the works of Yahaya et al. (2009). The concentration of heavy metals at the incinerator shows a relative decrease with distance from the source. This may be attributed to contamination of soil within the immediate vicinity of the incinerator by ash, which recorded high concentrations. Results revealed that iron $(\mathrm{F}=6.370)$, copper (27.043), zinc ( $\mathrm{F}=3.956)$, and Lead (34.546) had significant mean variations with distance from the incinerator i.e. at the base, 10 metres and 20 metres away (Table 2).

Results obtained for heavy metals analyzed in bottom ash collected from the UCH incinerator, showed $\mathrm{Zn}$ having the highest mean concentration of $10670 \mathrm{mg} / \mathrm{kg}$ while $\mathrm{Ni}$ had the lowest mean concentration of $34.78 \mathrm{mg} / \mathrm{kg}$. The descending order of metal content was $\mathrm{Zn}>\mathrm{Fe}>\mathrm{Cu}>\mathrm{Pb}>\mathrm{Cr}>\mathrm{Ni}$ (Table 1). Concentration of $\mathrm{Zn}$ in ash was relatively higher than the concentration reported by Zhao et al., (2010). The ash contains much higher amount of $\mathrm{Zn}$ than other metals, this is because $\mathrm{Zn}$ is found present in most of the items used in medical facilities: for example, metal alloys containing $\mathrm{Zn}$ and $\mathrm{Ti}$ are widely used in medical instruments (Zhao et al., 2010).

Table1: Summary of Concentration of Heavy Metals in Soils and Bottom Ash Samples Collected from and around UCH Incinerator, Basorun market Dumpsite and UI football field (Mean \pm Standard deviation) and USEPA Upper Limit for Heavy Metals in Soil

\begin{tabular}{llllll}
\hline Parameter & $\begin{array}{l}\text { UCH } \\
\text { (Incinerator) }\end{array}$ & $\begin{array}{l}\text { Bottom Ash } \\
\text { (UCH Incinerator) }\end{array}$ & $\begin{array}{l}\text { BASORUN } \\
\text { (Dumpsite) }\end{array}$ & $\begin{array}{l}\text { U.I. } \\
\text { (Control) }\end{array}$ & $\begin{array}{l}\text { USEPA } \\
(2002)\end{array}$ \\
\hline $\mathrm{Fe}(\mathrm{mg} / \mathrm{kg})$ & $185.22 \pm 72.88$ & $5357.52 \pm 4671.89$ & $290.67 \pm 78.66$ & $116.77 \pm 96.00$ & - \\
$\mathrm{Cu}(\mathrm{mg} / \mathrm{kg})$ & $16.22 \pm 13.13$ & $938.2 \pm 428.42$ & $7.86 \pm 1.68$ & $3.98 \pm 3.76$ & 1500 \\
$\mathrm{Zn}(\mathrm{mg} / \mathrm{kg})$ & $69.11 \pm 54.26$ & $10670 \pm 3852.44$ & $132.87 \pm 39.40$ & $16.41 \pm 2.35$ & 2800 \\
$\mathrm{Cr}(\mathrm{mg} / \mathrm{kg})$ & $2.33 \pm 2.53$ & $72.96 \pm 15.14$ & $2.58 \pm 1.48$ & $1.71 \pm 1.22$ & 1200 \\
$\mathrm{~Pb}(\mathrm{mg} / \mathrm{kg})$ & $22.48 \pm 21.00$ & $427.2 \pm 197.69$ & $14.52 \pm 6.76$ & $6.13 \pm 2.15$ & 300 \\
$\mathrm{Ni}(\mathrm{mg} / \mathrm{kg})$ & $0.58 \pm 0.30$ & $34.78 \pm 11.69$ & $0.79 \pm 0.26$ & $0.53 \pm 0.41$ & 420
\end{tabular}

Table 2: Mean Variation of Heavy Metal Concentrations in soil samples at different sampling points around the Incinerator at UCH

\begin{tabular}{lllll}
\hline Parameter & $\begin{array}{l}\text { A } \\
\text { (Base) }\end{array}$ & $\begin{array}{l}\text { B } \\
(10 \text { meters })\end{array}$ & $\begin{array}{l}\text { C } \\
(20 \text { meters })\end{array}$ & F value \\
\hline $\mathrm{Fe}(\mathrm{mg} / \mathrm{kg})$ & $265.33^{\mathrm{a}}$ & $144.0^{\mathrm{b}}$ & $146.33^{\mathrm{b}}$ & $6.370^{*}$ \\
$\mathrm{Cu}(\mathrm{mg} / \mathrm{kg})$ & $32.1^{\mathrm{a}}$ & $12.51^{\mathrm{b}}$ & $4.05^{\mathrm{b}}$ & $27.043^{*}$ \\
$\mathrm{Zn}(\mathrm{mg} / \mathrm{kg})$ & $105.9^{\mathrm{a}}$ & $85.6^{\mathrm{ab}}$ & $15.82^{\mathrm{b}}$ & $3.956^{*}$ \\
$\mathrm{Cr}(\mathrm{mg} / \mathrm{kg})$ & $2.76^{\mathrm{a}}$ & $3.09^{\mathrm{a}}$ & $1.15^{\mathrm{a}}$ & 0.437 \\
$\mathrm{~Pb}(\mathrm{mg} / \mathrm{kg})$ & $49.33^{\mathrm{a}}$ & $8.57^{\mathrm{b}}$ & $9.53^{\mathrm{b}}$ & $34.546^{*}$ \\
$\mathrm{Ni}(\mathrm{mg} / \mathrm{kg})$ & $0.35^{\mathrm{a}}$ & $0.70^{\mathrm{a}}$ & $0.68^{\mathrm{a}}$ & 1.451
\end{tabular}

Mean values along the same row with same alphabet are not significantly different

${ }^{* *}$ Values are significantly different $(\alpha=0.05)$

The t-test analysis of heavy metal concentrations for the soils collected around $\mathrm{UCH}$ incinerator and bottom ash samples collected from the incinerator all showed significant mean variation, $\mathrm{Ca}(\mathrm{t}=3.1525), \mathrm{Fe}$ $(\mathrm{t}=3.8345), \quad \mathrm{Cu} \quad(\mathrm{t}=7.4503), \quad \mathrm{Zn} \quad(\mathrm{t}=9.5310), \quad \mathrm{Cr}$ 
$(\mathrm{t}=15.8710), \mathrm{Pb}(\mathrm{t}=7.0392)$ and $\mathrm{Ni}(\mathrm{t}=10.1336)$ (Table $3)$.

Fe had the highest mean concentration (290.67 $\mathrm{mg} / \mathrm{kg})$, while $\mathrm{Ni}(0.79 \mathrm{mg} / \mathrm{kg})$ had the lowest mean concentration among all the heavy metals in soils from Basorun dumpsite (Table 1). The descending order of metal contents is $\mathrm{Fe}>\mathrm{Zn}>\mathrm{Pb}>\mathrm{Cu}>\mathrm{Cr}>$ Ni. Soil sample $10 \mathrm{~m}$ away from the dumpsite had relatively higher concentration of heavy metals than that from the base of the dumpsite. This may not be unconnected with the activities of butchers around that point. These butchers burn tires for roasting killed animals and mostly deposit the waste of animal parts generated such as horns and bones around that point. The relative low concentration at the base of the dumpsite may also be attributed to the presence of a flowing stream and sandy nature of the soil, which make leaching of soil components easier. When compared to USEPA regulation limits, all the metals at this site are below the specified limits (Table 1). The concentrations of heavy metal in these soils are also very low compared to that of polluted soils (Yahayaet al. 2009). The results obtained from the analysis of mean variance of the various concentrations of the heavy metals considered indicated that $\mathrm{Fe}(\mathrm{F}=4.480), \mathrm{Cu}(\mathrm{F}=4.531), \mathrm{Cr}(\mathrm{F}=$ 12.888) and $\mathrm{Pb}(\mathrm{F}=4.400)$ differ significantly at the three points of sampling with distance away from the dumpsite for heavy metals (Table 4).The general relatively higher concentration of heavy metals in soils at Basorun MSW dumpsite than in soils around UCH medical wastes (MW) dumpsite contradict reports by other researchers (Kuo et al., 1999, Ibanez, et al., 2000 and Zhao et al., 2010), who reported that heavy metals in medical residue are significantly higher than those in municipal solid waste. The results from the present study may not be unconnected with the fact that wastes are not allowed to be decomposed at the UCH incinerator, the point only serves as a collection point after which the wastes are moved to a designated, and government reserved dumpsite at Apete. At Basorun market dumpsite, the wastes are gathered there with no plan of moving them to another site. This implies that the soils at Bashorun market dumpsite poses more hazard to public health than the soils around the $\mathrm{UCH}$ incinerator

When compared to the report of Nwajei et al. (2007), the $\mathrm{Cr}$ levels are high in this study. Chromium functions in mammalian glucose metabolism and appears to be essential to man and animals (Yahayaet al. 2009). Higher concentration of Fe was recorded in this study than the concentration reported by Zhao et $a l$, (2010).

The $\mathrm{Pb}$ levels in soil were similar to the amount reported by Ogbonna et al. (2009) and Yahayaet al. (2009) but lower than the levels reported by Meneses et al. (1999) and Schuhmacher et al. (1997). The levels obtained in this work are high when compared to that reported by Nwajei et al. (2007). Higher concentration of $\mathrm{Pb}$ was recorded from ash than the concentration reported by Zhao et al., (2010). Ni levels in soil are lower than reported concentrations from the works of Meneses et al. (1999), Schuhmacher et al. (1997) and Yahaya et al. (2009). Concentration of $\mathrm{Ni}$ in ash was low compared to reports by Zhao et al. (2010).

Table 3: Mean Variation of Heavy Metal Concentration between Bottom Ash and Soil Samples Collected at

\begin{tabular}{llll}
\multicolumn{2}{c}{ UCH } & & \\
\hline Parameter & Soil Sample & Ash Sample & T-value \\
\hline $\mathrm{Fe}(\mathrm{mg} / \mathrm{kg})$ & 185.22 & 5357.52 & $3.8345^{*}$ \\
$\mathrm{Cu}(\mathrm{mg} / \mathrm{kg})$ & 16.22 & 938.2 & $7.4503^{*}$ \\
$\mathrm{Zn}(\mathrm{mg} / \mathrm{kg})$ & 69.12 & 10670 & $9.5310^{*}$ \\
$\mathrm{Cr}(\mathrm{mg} / \mathrm{kg})$ & 2.33 & 92.96 & $15.8710^{*}$ \\
$\mathrm{~Pb}(\mathrm{mg} / \mathrm{kg})$ & 22.48 & 427.2 & $7.0392^{*}$ \\
$\mathrm{Ni}(\mathrm{mg} / \mathrm{kg})$ & .58 & 34.78 & $10.1336^{*}$ \\
\hline
\end{tabular}

Mean variations along the same row with same alphabet are not significantly different

${ }^{* *}$ Values are significantly different $(\alpha=0.05)$

Table 4: Mean variation of Heavy Metals in Soils from the different sampling points at Basorun dumpsite

\begin{tabular}{lllll}
\hline Parameter & $\begin{array}{l}\text { A } \\
(\text { Base })\end{array}$ & $\begin{array}{l}\text { B } \\
(10 \text { metres })\end{array}$ & $\begin{array}{l}\text { C } \\
(20 \text { metres })\end{array}$ & F value \\
\hline $\mathrm{Fe}(\mathrm{mg} / \mathrm{kg})$ & $254.67^{\mathrm{b}}$ & $245.67^{\mathrm{b}}$ & $371.67^{\mathrm{a}}$ & $4.480^{*}$ \\
$\mathrm{Cu}(\mathrm{mg} / \mathrm{kg})$ & $6.96^{\mathrm{b}}$ & $9.61^{\mathrm{a}}$ & $7.03^{\mathrm{b}}$ & $4.531^{*}$ \\
$\mathrm{Zn}(\mathrm{mg} / \mathrm{kg})$ & 113.4 & 172.5 & 112.7 & 3.965 \\
$\mathrm{Cr}(\mathrm{mg} / \mathrm{kg})$ & $2.40^{\mathrm{b}}$ & $1.13^{\mathrm{b}}$ & $4.20^{\mathrm{a}}$ & $12.888^{*}$ \\
$\mathrm{~Pb}(\mathrm{mg} / \mathrm{kg})$ & $10.87^{\mathrm{b}}$ & $11.23^{\mathrm{b}}$ & $21.47^{\mathrm{a}}$ & $4.400^{*}$ \\
$\mathrm{Ni}(\mathrm{mg} / \mathrm{kg})$ & $0.77^{\mathrm{a}}$ & $0.79^{\mathrm{a}}$ & $0.81^{\mathrm{a}}$ & 0.012 \\
\hline
\end{tabular}

Mean variations along the same row with same alphabet are not significantly different

${ }^{* * *}$ Values are significantly different $(\alpha=0.05)$ 
The results recorded at University of Ibadan football field, which served as the control site showed that $\mathrm{Fe}$ $(116.77 \mathrm{mg} / \mathrm{kg})$ had the highest mean concentration while $\mathrm{Ni}(0.53 \mathrm{mg} / \mathrm{kg})$ had the lowest mean concentration among the heavy metals. The descending order of metal content is $\mathrm{Fe}>\mathrm{Zn}>\mathrm{Pb}>$ $\mathrm{Cu}>\mathrm{Cr}>\mathrm{Ni}$. When USEPA regulation limits are considered all the metals are under the specified limits (Table 1). These concentrations were lower than the concentrations in both soils at the incinerator and municipal dumpsite.

The analysis of variance results obtained for the period of study among the three sites showed that $\mathrm{Fe}$ $(\mathrm{F}=11.254), \mathrm{Cu}(\mathrm{F}=5.678), \mathrm{Zn}(\mathrm{F}=20.399)$ and $\mathrm{Pb}$ $(\mathrm{F}=3.679)$ had significant variations with sampling site.

Conclusion: The results from both locations were higher than their control site, indicating a clear case of pollution. Comparison of heavy metal concentration in soil with USEPA standards showed that they are all below the set limits. The soils at the Basorun municipal dumpsite had higher concentrations of heavy metals than the soils around the medical waste incinerator. Medical waste bottom ash is contaminated with high levels of heavy metals, with levels of $\mathrm{Zn}$ and $\mathrm{Pb}$, exceeding the USEPA standard limits. This type of waste ash poses serious threat to public health and should be disposed of appropriately.

\section{REFERENCES}

Baker, A. J. M., Reeves, R. D. and Hajar, A. S. M. (1996). Heavy metal accumulation and tolerance in British populations of the metallophyteThlaspicaerulescens J.\&C. Presl (Brassicaceae). New Phytol.127:61- 68.

Coker, A. O.,Akanmu, A. M.Sridhar, M. K. C.and Aladenola, I. O.(2000).Management of pollution from an hospital incinerator in Nigeria. International conference on air pollution $\mathrm{N}^{\circ} 8$, Cambridge, ROYAUME-UNI 2000, pp. 253-260[Note(s): [786 p.]]

Ibanez, R., Andres, A., Viguri, J.R., Ortiz, I. and Irabien, J.A. (2000).Characterisation and Management of Incinerator Wastes.J. Hazard. Matter. 79:215-227.

Kuo, M.W., Shu, S.L., Wu, C.C., Lai, J.S. (1999). Characteristics of Medical Waste in Taiwan, Water Air Soil Pollution. 114:413-421.

Mahoney, D.B. and Moy, G. C. (2005).Food borne hazards of particular concern to children. In: Pronczuk de Garbino J. Editor. Children's Health and the Environment, a Global Perspective: A Resource Manual for the Health Sector. Chapter 11.
Mehlich, M. (1984).Mehlich 3 soil test extractant: a modification of the Mehlich 2 extractant. Comm. Soil Sci. Plant Anal. 15:1409-1416

Meneses, M.; Llobet, S.; Granero, S.; Scuhmacher, M. and Domingo, J.L. (1999).Monitoring metals in the vicinity of a municipal waste incinerator: temporal variation in soils and vegetation.Sci. Total Environ. 226: $157-164$.

National Population Comission (2007).Census 2006.Oyo State Local Government Figures and other activities of the Commission. Pp 16

Nwajei, G.E., Iwegbue, C.M.A. and Okafor, M.I. (2007).Heavy Metals in Surface Soils under Waste Dumps from Onitsha Nigeria.J. Biol. Sci. Asian Network for Scientific Information. 7(2): 405-408.

Ogbonna, D.N.; Kii, L.B. and Youdeowei, P.O. (2009).Some Physico-chemical and Heavy Metals levels in soils of waste dumpsites in Port Harcourt Municipality and Environs.J. Appli. Sci. Environ. Manage. Vol. 13(4): 65-70

Onibokun, A.G. (1999). Managing the Monsters: Urban Waste and Governance in Africa.International Development Research Centre. Ottawa

Scuhmacher, M.; Meneses, M.; Granero, S.; Llobet, J.M. and Domingo, J.L. (1997). Trace Element Pollution of Soils Collected near a Municipal Solid Waste Incinerator: Human Health Risk. Bull. Environ. Contam.Toxicol. 59: 861-867

USEPA (2002).Biosolids Applied to Land: Advancing Standards and Practices. National Research Council, National Academy Press, Washington, DC, p. 282.

World Health Organisation (2005). Children's Health and the Environment: A global Perspective: a resource manual for the health sector. Pronczuk de Garbino J. (Ed.)

World Health Organisation (2006). Preventing Disease through Healthy Environments; Towards an Estimate of the Environmental Burden of Disease

Yahaya, M.I., Mohammed, S. and Andullahi, B.K. (2009). Seasonal Variations of Heavy Metals Concentration in Abattoir Dumping Site Soil in Nigeria.J. Appli. Sci. Environ. Manage. Vol. 13(4): 9-13.

Zhao, L., Zhang, F., Chen, M., Liu, Z. and Wu, D.B.J. (2009).Typical Pollutants in Bottom Ash from a Typical Medical Waste Incinerator.J. Haz. Mat. 173(2010):181-185 